\title{
KONVERGENSI MEDIA DAKWAH DI MASA PANDEMI COVID 19
}

\author{
Mada Wijaya Kusumah \\ Prodi Komunikasi Penyiaran Islam, STIBA Ar Raayah Sukabumi, Indonesia \\ madawijayakusumah@gmail.com
}

\begin{abstract}
Abstrak
Penelitian ini bertujuan untuk menemukan adanya konvergensi media dakwah di masa pandemi Covid 19. Media dakwah yang banyak ragamnya dibutuhkan oleh Dai. Di masa pandemi Covid 19 yang tengah mewabah ini, media dakwah menjadi sangat penting sebagai media paling efektif dan aman dalam menyampaikan Islam pada masyarakat Indonesia. Penelitian ini menggunakan metode campuran, yaitu dengan pendekatan kepustakaan atau studi literatur juga studi analisa media sosial. Hasil penelitian ini menunjukkan bahwa masa pandemi Covid 19, para ulama, habaib dan kyai menjadikan konvergensi media dakwah sebagai media dakwah Islam untuk meningkatkan kesadaran umat. Adanya konvergensi Media Dakwah ini telah menjadi inovasi baru dalam geliat syiar dakwah Islam. Sejak tanggal kemunculan Covid 19, 31 Desember 2019, subscribers pendakwah nasional pada salah satu platform dakwah telah bertambah 3.149 subscribers. Aplikasi Zoom Meeting, Google Meet, Skype adalah media yang paling banyak digunakan oleh para ulama, habaib dan kyai dalam menyampaikan Islam sebagai solusi bagi negeri ini. Dari aplikasi tersebut dipublikasikan secara masif pada berbagai kanal dakwah Youtube yang mampu menampilkan visual, menghadirkan audio dan gambar.
\end{abstract}

Kata kunci : Konvergensi Media, Dakwah, Teknologi, Covid 19

\section{Pendahuluan}

Saat ini telah banyak Da'I yang memfokuskan objek dakwahnya, ada yang memfokuskan pada segmen remaja dan pemuda; ada yang memfokuskan pada ibu-ibu pengajian; ada yang memfokuskan pada anak-anak dan ada yang memfokuskan pada kaum akademisi dan pengusaha.

Begitu pula ada aneka ragam media yang digunakan oleh para Da'I, mulai dari televisi, radio, internet dan buku. Dengan banyaknya aplikasi pada smartphone, segmen dakwah pun kian beragam, ada jamaah yang hanya senang

Artikel ilmiah pada seminar nasional daring "Dakwah dimasa pandemi covid-19" yang diselenggarakan oleh Program studi komunikasi penyiaran islam, sekolah tinggi ilmu bahasa arab Ar-Raayah Sukabumi, tanggal 5 Juli 2020 
membaca materi kajian pada Whatsapp Grup; ada yang senang quotes pada Twitter; ada yang senang menyimak kajian video pada Youtube.

Maka timbulah pertanyaan apakah memungkinkan terjadinya perpaduan beragam jenis media-media yang ada, yang menghadirkan visual, audio, jaringan internet, gambar dan lainnya menjadi kesatuan media dakwah? Konvergensi media dakwah di masa pandemi Covid 19. dirasa menjadi kebutuhan masyarakat Islam, alasannya bila seseorang membaca buku saja lalu bagaimana bila ada yang hendak ditanyakan. Bila seseorang mendengarkan radio saja, lalu bagaimana ia dapat melihat gambaran visual yang dijelskan? Oleh karena itu konvergensi media dakwah adalah penting digunakan sebagai untuk meningkatkan tingkat pemahaman komunikan (mad'u) atas materi (pesan dakwah) yang disampaikan para Da'I (komunikator). Media dakwah ini pun perlu memenuhi kriteria aman bagi kesehatan semua pihak, jangan sampai terjadi penggunaan suatu media dakwah menambah luas penyebaran virus Corona 19.

\section{Metode Penelitian}

Penelitian ini menggunakan metode campuran (mixed methods). Pada penelitian ini dilakukan studi kepustakan dan literatur, serta analisis media sosial dakwah. Beberapa aplikasi analisis media social yang digunakan adalah Google Trends dan Telegram Analytics.

\section{Hasil dan Pembahasan}

\section{Pengertian Konvergensi Media Dakwah}

Konvergensi memiliki arti penggabungan atau pengintegrasian (berasal dari bahasa Inggris "convergence"). Maksud dari konvergensi ialah adanya dua hal/benda atau lebih yang bertemu dan bersatu dalam suatu titik. Konvergensi media adalah penggabungan berbagai media yang ada untuk digunakan dan diarahkan ke dalam satu tujuan, misalnya dakwah Islam.

Media-media konvensional di masa lalu di antaranya surat kabar, radio, televisi, dan telepon, semua media ini dapat terintegrasi menjadi satu berupa media digital. Maka konvergensi media dakwah adalah adanya kolaborasi berbagai elemen (platform) media yang menjadi sarana dakwah Islam untuk meningkatkan kesadaran umat. Konvergensi media dakwah merupakan integrasi teks, audio, video sebagai sarana dakwah Islam untuk meningkatkan kesadaran umat.

\section{Awal Hadirnya Media Cetak bagi Dakwah di Indonesia Terdapat beragam Media Dakwah di Masa Lalu}

Sebelum kemerdekaan RI, para ulama telah mengharumkan Nusantara dengan berbagai karya tulis yaitu penulisan Kitab. Beberapa ulama yang membawa nama harum Indonesia adalah : Syeikh Abdus Shomad Al-Palimbani, Syeikh Arsyad Al Banjari, Syeikh Abdul Wahab Al-Bugisi, Syeikh An-Nawawi Albantani, Syeikh 
Ahmad Khatib Al Minangkabawi, Syeikh Yasin Al-Fadani, Syeikh Mahfudz AtTarmasi dan ulama lainnya.

Karena betapa besarnya kiprah dakwah para ulama ini, maka saat ini telah banyak kegiatan penelitian pada pusat kajian manuskrip keagamaan nusantara yang dilakukan Kementrian Agama. Begitu pula pada tingkat universitas terdapat konsentrasi Kajian Pemikiran Pendidikan Islam pada program studi Pendidikan Agama Islam.

\section{Awal Hadirnya Media Cetak bagi Dakwah di Indonesia}

Selain melalui Kitab Kuning, pada pra Kemerdekaan RI, yaitu di akhir masa kejatuhan Institusi Persatuan Umat Islam (Khilafah Utsmaniyah), di Nusantara telah hadir berbagai surat kabar Islam yang diinisiasi ulama hadromi dan ulamaulama yang bergerak di berbagai organisasi dakwah Islam pra Kemerdekaan RI.

Surat Kabar Al Imam sejak 1906 disebut sebagai media massa Islam pertama yang diterbitkan Syekh Tahir Jalaluddin, Syekh Al Hadi, H. Abbas bin M. Taha (Aceh).

Kemudian pada 1913, Sarekat Islam, pimpinan H. Omar Said Tjokroaminoto menerbitkan beberapa surat kabar yaitu Oetoesan Hindia di pusat, juga Hindia Serikat di Bandung dikelola Abdul Muis, Pantjaran Warta di Batavia, Sinar Djawa diterbitkan di Semarang.

Adapun yang berupa Majalah pada 1911, majalah Al Munir terbit di Sumatera Barat oleh H. Abd. Al Munir, H. Abdul Karim Amrullah dan Syekh Jamil Jambek*. Hadramaut* terbit di Surabaya (1922-1926). Kemudian pada1922, Bintang Islam terbit dwi mingguan oleh H. Fachrodin (Muhammadiyah). Karena dikelola secara professional. Tirasnya mencapai 1500 eksmeplar dan menjangkau Singapura, Perak dan Johor. Pada 1929, Pembela Islam diterbitkan dua bulanan oleh Persatuan Islam Bandung. A. Hassan Bersama Fachrudin Al Kahiri dan M. Natsir, merintis pers Islam yang gigih membela Islam melawan dari ide sekularisme, nasionalisme. Adapun Nadhlatul Ulama menerbitkan Suara NU yang beraksara arab pegon. Berita NU yang beraksara latin dikelola KH Mahfudz Shiddiq. Pada 1941 terbit Soeloeh NU dipimpin KH A. Wahid Hasyim.

Munculnya beragam organisasi Islam di Indonesia tidak lepas dari keadaan dunia Islam yang mengalami masa kolonial oleh bangsa Eropa dan adanya upaya membangkitkan dan merajut kembali persatuan umat Islam baik di nusantara juga dunia Internasional. Hal ini terbukti dengan adanya utusan dan penyelenggaraan konferensi Islam serta upaya perjuangan kemerdekaan. 


\section{Bahasa Arab, Daerah dan Indonesia menjadi bahasa Dakwah di Indonesia}

Berdakwah yang efektif tentu dengan menggunakan bahasa masyarakat setempat. Namun mendorong umat memahami bahasa Islam sebagai bahasa yang digunakan dalam beribadah dan Ilmu pengetahuan adalah menjadi hal yang berharga.

Dengan banyaknya majelis, pesantren yang mengajarkan kitab Turats pada halaqat ulama-ulama Indonesia sekembalinya dari Mekah mendorong dikembangkannya bahasa Arab Melayu/Pegon. Pada beberapa karya ulama kita dapati kitab tersebut ditulis dengan bahasa Arab, ada juga dengan Arab Melayu, dengan bahasa Daerah dan kini banyak ditulis dengan bahasa Indonesia

\section{Awal Hadirnya Media Audio-Visual}

Dalam catatan sejarah, embrio dari Radio adalah saat adanya ide untuk memanfaatkan gelombang elektromagnetik yang kasat mata, yang bergerak lewat udara dengan kecepatan suara untuk dimanfaatkan sebagai pengirim tandatanda.

Dari penelitian Guglielmo Marconi, maka pada 1896 ditemukan telegraf nirkabel. Kemudian Edwin Howard Armstrong mengembangkan modulasi frekuensi (FM) pada 1933.

Pada pra Kemerdekaan RI ini pemerintahan Belanda di Batavia membuat Radio amatir Batavia Radio Vereeneging (BRV) pada 1926. Kemudia munculah siaran Nederlandsche Radio Omroop Maatscapy (NROM) di Batavia pada 1934

Adapun sejarah Televisi, pada 1927, John Logie Baird, Charles Francis Jenkins, Philo Taylor Franswoth, merintis TV sederhana. Dan demonstrasi televisi bagi masyarakat Indonesia ada pada 1955. Pada 25 Juli 1961, mulai ada komite persiapan pembentukan televisi di Indonesia. Setelah ada studio, menara siaran, dan peralatan teknis di tempat bekas Akademi Informasi di Senayan. Siaran TV percobaan pertama mengudara oleh TVRI, pada hari kemedekaan 1962.

\section{Awal Hadirnya Media Audio-Visual bagi Dakwah di Indonesia}

\section{Radio di Masa Lalu}

Radio Republik Indonesia berdiri pada 11 Sep. 1945. Ulama Islam KH. R. Abdullah bin Nuh (1905-1987) berperan dalam memberitakan kemerdekaan Indonesia dalam bahasa Arab yang terdengar hingga Timur Tengah. Terdapat Radio Frekuensi AM swasta yaitu Cendrawasih yang berdiri 1966 oleh Sehan Alatas. Cendrawasih telah merelay kajian dari beberapa majelis di Jakarta yaitu al-Habsiy Kwitang, Darul Mustafa dan Darul Afaf. KH. Buya HAMKA: H. Abdul Malik Karim Amrullah (1908-1981) pun turut berkontribusi membina umat melalui siaran udara ini. 
Di antara progam dakwah melalui radio ialah dengan memperdengarkan caramah ulama atau dai nusantara di setiap Bada Subuh. Misalnya memutarkan mp3 kajian KH. Zainuddin (Hamidi) MZ (1951-2011), maka Kaset Ceramah, Qashidah, Nasyid turut mengisi program religi Radio Islam.

\section{Televisi di Masa Lalu}

Kesan yang masih saya ingat adalah saat menonton acara TVRI. Saat kecil, yang memiliki TV sangat jarang, sehingga 1 TV ditonton oleh banyak keluarga. Program acara TV yang menghadirkan kesederhanaan, kebersamaan hidup masyarakat pada umumnya ada pada TVRI. Adapun program TV Swasta saat ini umumnya menayangkan film fantasi, action dan kehidupan kelas atas (glamor).

Melalui penelusuran Youtube, Jalan-Jalan Islami TVRI yang ada sejak 2010 adalah program religi TVRI yang berusaha menyampaikan aneka ragam dakwah Islam di berbagai pelosok negeri. Tidak dipungkiri televisi telah memberikan informasi serta pembelajaran kepada khalayak mengenai sejarah perkembangan agama Islam di Indonesia.

\section{Awal Hadirnya Media Internet bagi Dakwah di Indonesia}

Sejak 1988, ada Internet di Indonesia yang memanfaatkan CIX (Inggris) dan Compuserve (AS) untuk mengakses internet. Laboratorium Internet UI-NETLAB dengan IP Adress 192.41.206/24 adalah yang didaftarkan pertamakali untuk menjalankan internet pada 24 Juni 1988. RMS Ibrahim, S. Adisoemarta, M.Ihsan, R. Soebiakto, Putu, F, Siregar, A. Indrayanto, dan Onno W. Purbo merupakan pembangunan Internet Indonesia pada tahun 1992 hingga 1994.

Melalui proyek Advanced Research Project Agency Network (ARPAnet) di AS pada tahun 1969 internet diperkenalkan pada dunia. Setelah dibukanya IndoNet pada 1994 di Jakarta sebagai internet service provider (ISP) pertama di Indonesia yang menyediakan internet komersial bagi publik maka di 1998-1999 berkembanglah dakwah melalui Internet.

Pada tahun tersebut dakwah mahasiswa Islam bergejolak, melalui Lembaga Dakwah Kampus tumbuh di banyak universitas.

Dakwah kian ramai dengan adanya mailing-list (milis) semisal Isnet, alIslam, dan Padang Mbulan. Milis ialah grup diskusi di Internet yang memungkinkan pengguna internet bisa bergabung menyimak postingan materi Islam secara berlangganan, begitu pula dapat melakukan dialog Islam didalamnya. Memang saat itu email sebagai media utama komunikasi pada internet.

Setelah banyaknya situs-situs (website) Islam di tahun 1999-2000 maka internet menjadi salah satu media rujukan dan media dakwah Islam Indonesia.

Perkembangan selanjutnya adalah adanya ebook dalam bentuk help (kompilasi naskah dakwah format*.html), juga ebook berupa PDF. 
Dr Muhammad Sa'id Ramadhan al-Buthi sebagaimana dikutip oleh Erni Arie Susanti (Staf Infokom Jakarta Islamic Centre) berkata, "Ternyata jaringan internet yang hampir menelan seluruh penjuru dunia adalah merupakan lahan luas yang di situ bertebaran mimbar-mimbar yang menyuarakan kepentingan Islam, dengan memperkenalkan, mengajak (dakwah), membela dan memecahkan berbagai problemanya."

Ragam media dakwah di masa lalu

\begin{tabular}{|c|c|c|c|}
\hline No & $\begin{array}{l}\text { Ragam } \\
\text { Dakwah }\end{array}$ & $\begin{array}{l}\text { Pesan Dakwah yang } \\
\text { Disampaikan }\end{array}$ & Periode \\
\hline 1 & $\begin{array}{l}\text { Media Cetak } \\
\text { (Mushaf Al-Quran, } \\
\text { Kitab Hadits) }\end{array}$ & $\begin{array}{l}\text { Ayat Al-Quran, Matan } \\
\text { dan Sanad Hadits, Tafsir }\end{array}$ & Masa Shahabat Rasulullah hingga kini \\
\hline 2 & $\begin{array}{l}\text { Media Lisan } \\
\text { (Talaqqi Al-Quran, } \\
\text { penyampaian } \\
\text { Hadits) }\end{array}$ & $\begin{array}{l}\text { Ayat Al-Quran, Matan } \\
\text { dan Sanad Hadits, Tafsir, } \\
\text { Bahasa Arab }\end{array}$ & Masa Rasulullah saw. hingga kini \\
\hline 3 & Media Individual & $\begin{array}{l}\text { Keteladanan ulama, } \\
\text { praktik Ibadah }\end{array}$ & Masa Rasulullah saw. hingga kini \\
\hline 4 & $\begin{array}{l}\text { Media Cetak (Kitab } \\
\text { Kuning) }\end{array}$ & Syariah (ajaran) Islam & $\begin{array}{l}\text { Perkiraan ada sejak Abad } 12 \text { H. yaitu saat } \\
\text { ulama-ulama masyhur ada di Nusantara, } \\
\text { diantaranya Syeikh Abdus Shomad Al- } \\
\text { Palimbani, Syeikh Arsyad Al Banjari, Syeikh } \\
\text { Abdul Wahab Al-Bugisi, Syeikh An-Nawawi } \\
\text { Albantani, Syeikh Ahmad Khatib Al } \\
\text { Minangkabawi, Syeikh Yasin Al-Fadani. }\end{array}$ \\
\hline 5 & $\begin{array}{l}\text { Media Cetak (Surat } \\
\text { Kabar, Majalah) }\end{array}$ & $\begin{array}{l}\text { Ajaran } \\
\text { Dunia } \\
\text { Islam, } \\
\text { Islam }\end{array}$ & $\begin{array}{l}\text { 1906 : Al Imam di Sumatera } \\
\text { 1911, Al Munir di Sumatera Barat } \\
\text { 1913, dari Sarekat Islam: Oetoesan Hindia; } \\
\text { Hindia Serikat; Pantjaran Warta; Sinar } \\
\text { Djawa. } \\
\text { 1922, Hadramaut di Surabaya } \\
\text { 1922, Bintang Islam dari Muhammadiyah } \\
\text { 1924, Medan Moeslimin } \\
\text { 1929, Pembela Islam dari Persatuan Islam } \\
\text { 1941, terbit Soeloeh NU }\end{array}$ \\
\hline 6 & Media Radio & $\begin{array}{l}\text { Pesan Perjuangan umat } \\
\text { Islam Indonesia } \\
\text { Program Siaran Radio } \\
\text { Islam }\end{array}$ & $\begin{array}{l}\text { 1945, Radio Republik Indonesia. Padanya } \\
\text { KH. R. Abdullah bin Nuh turut berperan. } \\
\text { 1966, Radio AM Cendrawasih di Jakarta } \\
\text { dan KH. Buya HAMKA: H. Abdul Malik } \\
\text { Karim Amrullah pun turut berkontribusi } \\
\text { melalui siaran udara ini. }\end{array}$ \\
\hline 7 & Media Televisi & $\begin{array}{l}\text { Program Siaran Religi } \\
\text { Islam }\end{array}$ & 1962, TVRI \\
\hline 8 & Media Internet & $\begin{array}{l}\text { Diskusi Islam dan artikel } \\
\text { Islami }\end{array}$ & $\begin{array}{l}1994 \text { khususnya sejak } 1998 \text { berkembang } \\
\text { dakwah melalui milis Internet. }\end{array}$ \\
\hline
\end{tabular}




\section{Pandemi Covid 19}

Informasi awal adanya Pandemi Corona ini dimulai sejak adanya laporan WHO pada 31 Des 2019 adanya kasus Kluster Pneumonia tak dikenal di Wuhan Hubei China yang berlangsung hingga hari ini. Dengan meluasnya Pandemi Covid di berbagai belahan negara di dunia menyebabkab telah membatasi gerak masyarakat, kemudian diberlakukanlah : a) Social distancing, dan b) Physical distancing. Dengan adanya Pandemi masyarakat terdorong untuk menjadikan media internet dan media sosial sebagai sarana untuk komunikasi, pendidikan, pekerjaan, termasuk untuk dakwah (penyampaian Islam), dan me-Ngaji Islam.

Pada awalnnya penyampaian Dakwah Islam dicukupkan melalui berbagai Program TV Islami pada TV Streaming, TV Kabel, TV Parabola atau dengan program Siaran Radio Islami dari pemancar-pemancar Radio Frekuensi FM, AM, SW begitupula melalui media Cetak seperti Majalah, Tabloid, Koran, Buletin; akan tetapi di masa Pandemi ini ada kebutuhan lebih yaitu perlunya tatap muka Dai dan Mad'unya, Ustadz dan Jamaahnya, maka kini banyak majelis, seminar Islam dan multaqo ulama yang memanfaatkan aplikasi meeting internet dalam berdakwah.

\section{Konvergensi Media Dakwah di Masa Pandemi}

Konvergensi media dakwah Islam kini telah hadir menjembatani jarak antara umat dengan para ulama, habaib dan kyai. Melalui kehadiran smartphone juga notebook dengan aplikasi Zoom, Google-Meet, FCC, Cisco Webex, Teams, Skype suasana dakwah semakin merebak.

Konvergensi industri media dan teknologi digital dikenal sebagai komunikasi multimedia. Multimedia atau media campuran ialah sebagai medium yang mengintegrasikan dua bentuk komunikasi atau lebih. Smartphone dan notebook kini telah menjadi media mengakomodir banyak kebutuhan.

Media adalah sesuatu yang dapat digunakan sebagai sarana penghubung atau perantara dalam penyampaian informasi dari pengirim kepada penerima informasi.

Melalui penggunaan aplikasi konferensi (Zoom, Google-Meet, FCC, Cisco Webex, Teams, Skype) terjadi koeksistensi efisien telepon, video dan komunikasi data dalam satu jaringan.

Pada kondisi jaringan yang baik, dakwah melalui webinar terasa lebih nyaman. Pesan dakwah dapat disampaikan secara tatap muka melalui internet yang dapat dilengkapi data berupa teks, audio dan video. Penggunaan media ini juga menjadi solusi atas jarak yang saling berjauhan.

Pesan dakwah yang terekam pada akhirnya dapat dibuka kembali oleh audiens (khalayak) media massa dan dibuka kapan pun, di mana pun. Bila ruang chat tersedia maka dialog dapat dilanjutkan kembali. 


\section{Beberapa Data Penggunaan Media Dakwah di Masa Pandemi}

Peneliti telah mengambil beberapa contoh organisasi dakwah, tokoh ustadz dan yayasan yang dapat menunjukan perbedaan antara Dakwah sebelum Pandemi dan Dakwah di Masa Pandemi.

Grafik berikut ini menunjukkan angka pengguna Media Sosial (khususnya: Telegram salah satu Organisasi Islam) sebelum adanya wabah Corona. Pada tanggal 08 Oktober 2019 subscribers berjumlah 7.177 orang kemudian pada 30 Desember 2019 berjumlah 7.460 orang.

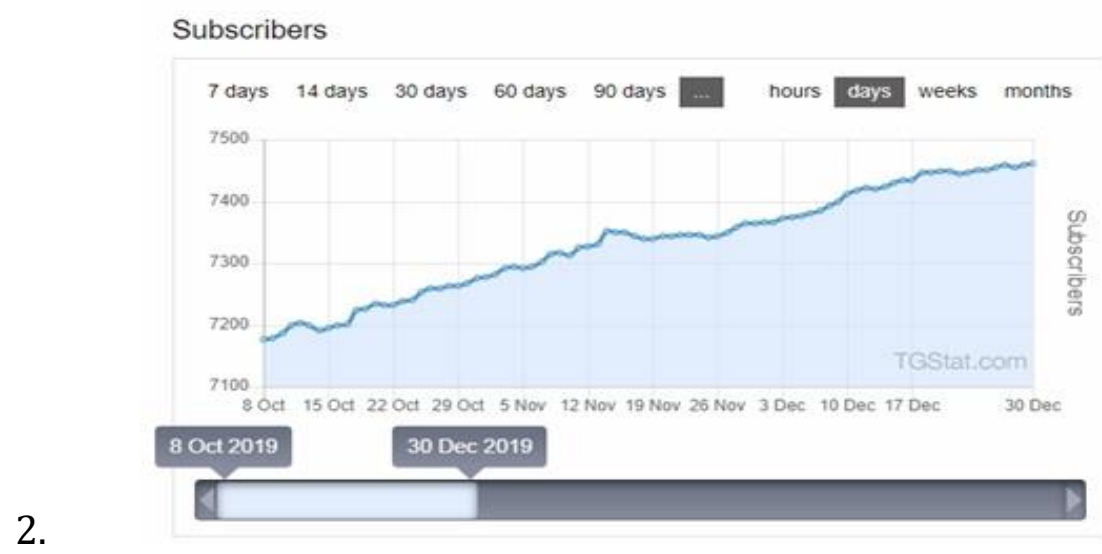

https://i.imgur.com/hOhpina.jpg

Grafik berikut ini menunjukkan adanya peningkatan angka pengguna Media Sosial (khususnya: Telegram salah satu Organisasi Islam) di masa pandemi Corona 19. Pada tanggal 31 Desember 2019 subscribers berjumlah 7.177 orang kemudian pada 3 Juli 2020 berjumlah 8.948 orang.

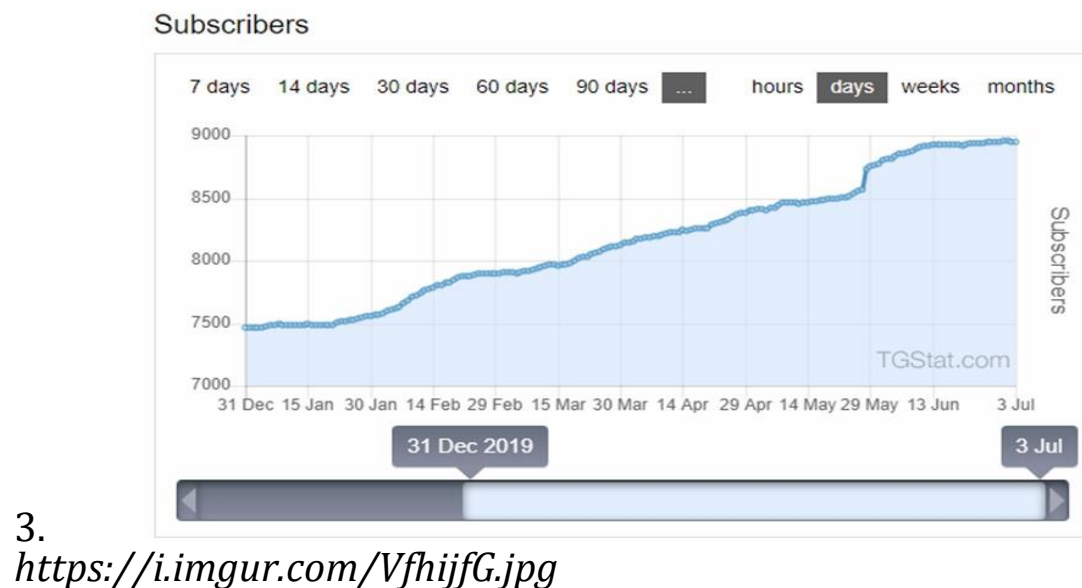

Grafik berikut ini menunjukkan angka pengguna Media Sosial (khususnya: Telegram salah satu Dai Nasional) sebelum adanya wabah Corona. Pada tanggal 17 Januari 2019 subscribers berjumlah 15.402 orang kemudian pada 30 Desember 2019 berjumlah 16.951 orang. 
4.

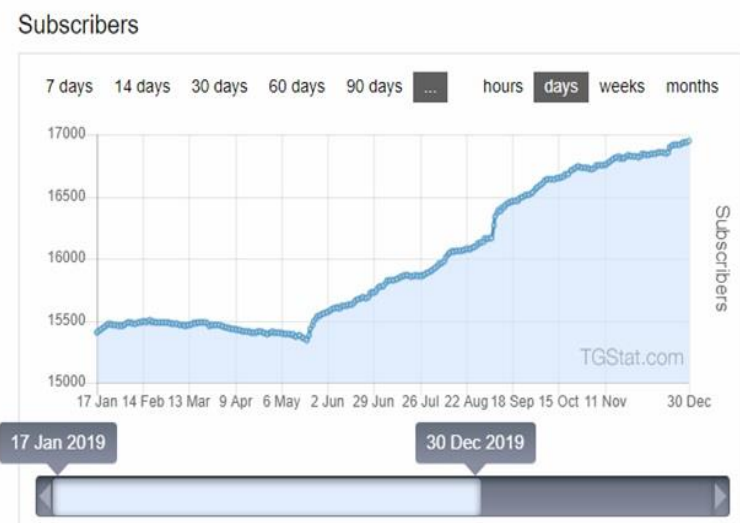

Recent posts

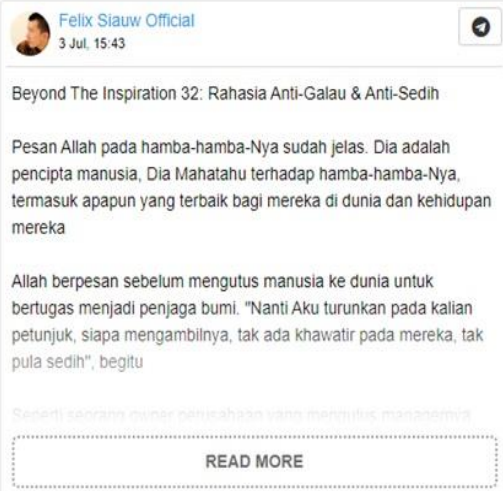

https://i.imgur.com/GsinYQn.jpg

Grafik berikut ini menunjukkan adanya peningkatan angka pengguna Media Sosial (khususnya: Telegram salah satu Dai Nasional) di masa pandemi Corona 19. Pada tanggal 31 Desember 2019 subscribers berjumlah 16.951 orang kemudian pada 4 Juli 2020 berjumlah 20.100 orang.

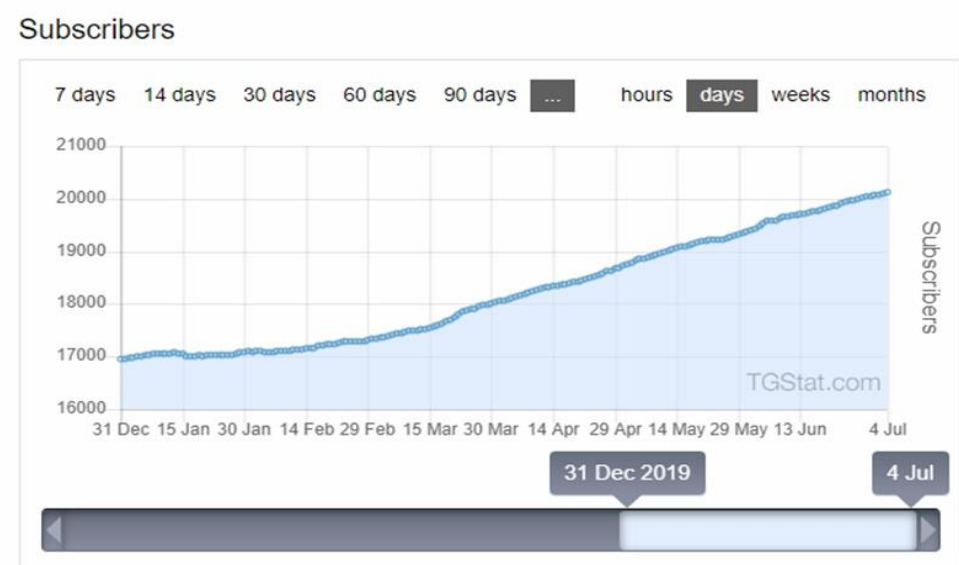

5. https://i.imgur.com/hVkalFC.jpg

Dari grafik tersebut menunjukan masyarakat Indonesia saat Pandemi Covid 19 memilih penggunaan media sosial dalam mengikuti kajian Islam. Berikut ini grafik yang menunjukan penggunaan media social seiring berjalannya waktu, yaitu;

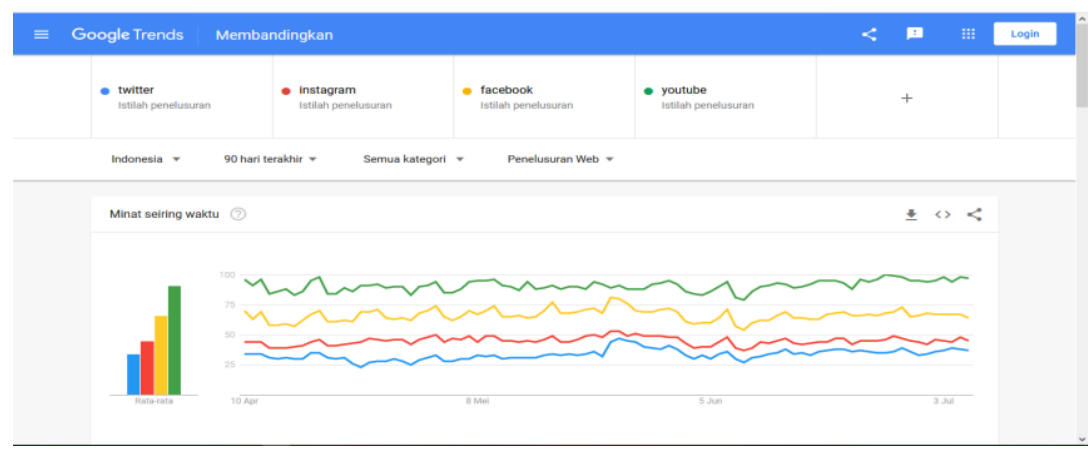




\section{Dakwah Ulama Aswaja Melalui Webinar}

Dalam menyikapi Pandemi Corona 19, berbagai agenda dakwah tingkat daerah bahkan nasional oleh para ulama, habaib dan kyai tetap dilakukan dengan melalui website seminar (webinar). Kini penggunaan aplikasi Zoom, Google-Meet, menjadi sarana berdakwah di masa Covid 19.

Melalui pengamatan pada website https://shautululama.co/ didapatkan banyak pemberitaan telah terselenggaranya multaqo (pertemuan akbar) para ulama yang ada dari bagian Barat Indonesia yaitu Aceh hingga Timur Indonesia yaitu Papua. Semangat dakwah ini seharusnya menjadi pemicu dakwah umat Islam. Keistiqomahan mereka sebagai waratsah al-anbiya hendaknya diteladani oleh para Da'i-Da'I muda.

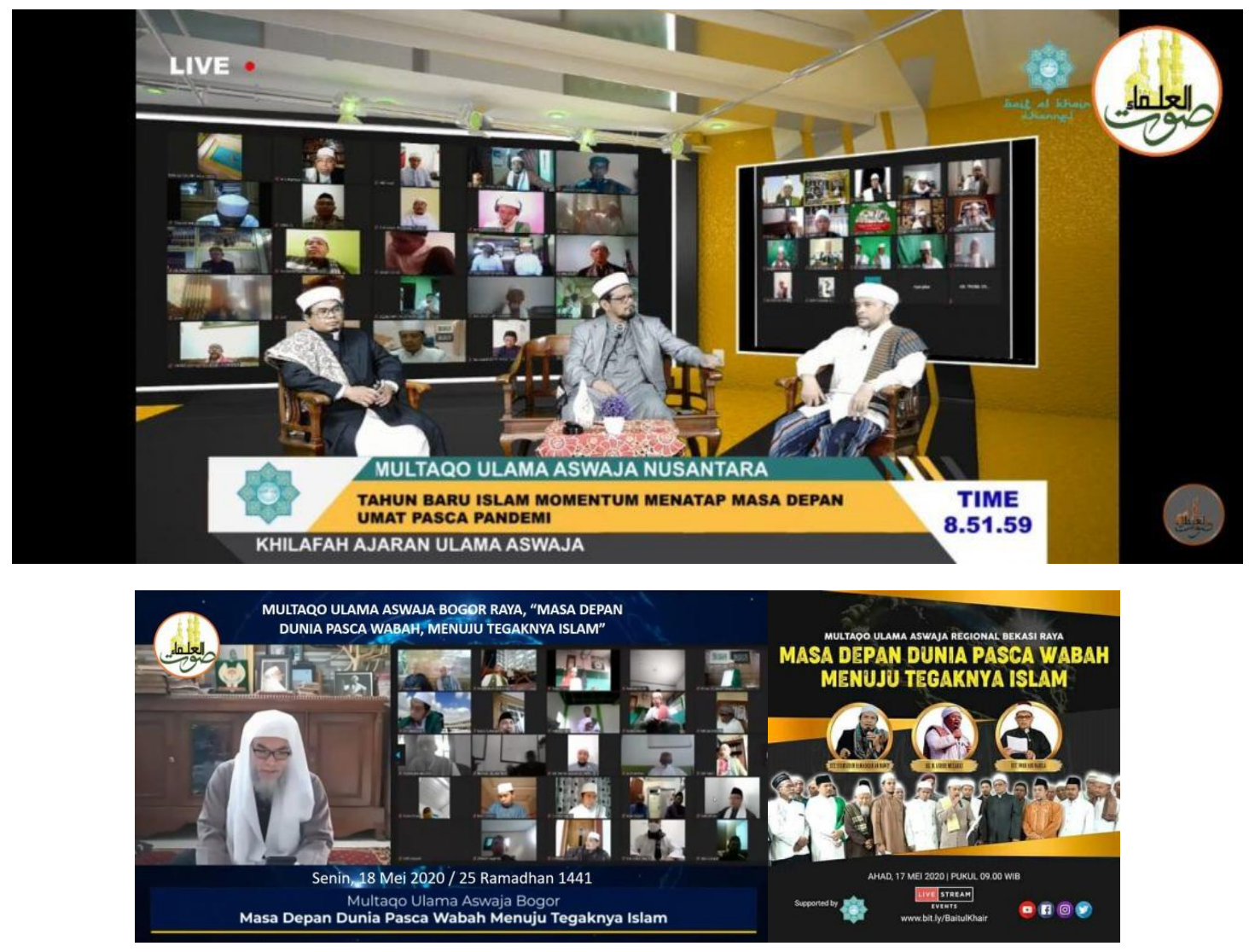

Para da'i atau mubaligh baik personal maupun lembaga dakwah kemudian memanfaatkan Youtube untuk memperluas dakwahnya. Mereka menyampaikan tema aqidah, fiqih ibadah, Al-Quran, akhlak termasuk membahas solusi atas permasalahan kekinian negara sekular saat ini agar terlepas dari problematika politik, ekonomi, sosial yang kini dihadapi (Rahma \& Kusumah, 2020).

Adapun pesan dakwah yang disampaikan para ulama, habaib dan kyai pada kegiatan dakwah di tengah wabah Corona adalah sebagai berikut. 


\begin{tabular}{|c|c|c|c|}
\hline No & Ulama & Pesan Dakwah & Tautan \\
\hline 1 & $\begin{array}{l}\text { KH Abdul Qoyum } \\
\text { Ulama Aswaja } \\
\text { Malang }\end{array}$ & $\begin{array}{l}\text { "Dakwah wali songo itu meliputi bidang politik, } \\
\text { pemerintahan, kekuasaan dan kenegaraan yang dilakukan } \\
\text { dengan lemah lembut, penuh kasih sayang, keluhuran budi, } \\
\text { manisnya tutur kata, keceriaan wajah, senyum manis dan } \\
\text { kebaikan akhlak." }\end{array}$ & $\begin{array}{l}\text { s.id/qEV } \\
\text { GU }\end{array}$ \\
\hline 2 & $\begin{array}{l}\text { Kyai Abdulloh } \\
\text { Amroni Ulama } \\
\text { Probolinggo }\end{array}$ & $\begin{array}{l}\text { "Wabah ini juga harus diselesaikan dengan ikhtiar kita, dan } \\
\text { yang paling bertanggung jawab adalah penguasa yang ada. } \\
\text { Penguasalah yang harus berupaya sekuat tenaga } \\
\text { mengupayakan dengan segala kemampuannya dengan } \\
\text { berbagai potensi yang ada untuk menyelesaikan wabah ini." }\end{array}$ & $\begin{array}{l}\text { youtu.be/ } \\
\text { SRUEQUa } \\
\text { KRT4 }\end{array}$ \\
\hline 3 & $\begin{array}{l}\text { Kyai Syakhrowardi } \\
\text { Ulama Banten }\end{array}$ & $\begin{array}{l}\text { "Khilafah itu syariat Rasulullah saw untuk menegakkan Islam } \\
\text { secara kaffah." }\end{array}$ & $\begin{array}{l}\text { youtu.be/ } \\
\text { natzb- } \\
\text { G4xt8 }\end{array}$ \\
\hline 4 & $\begin{array}{l}\text { Kyai Baihaqi al } \\
\text { Munawwar Ulama } \\
\text { Kalimantan Selatan }\end{array}$ & $\begin{array}{l}\text { "Setelah sistem komunisme lumpuh, saat ini sistem } \\
\text { kapitalisme sekarat, alternatif satu-satunya adalah Islam. } \\
\text { Saatnya umat Islam menatap masa depan, dengan _himmah_ } \\
\text { yang tinggi yang merupakan bagian dari iman," }\end{array}$ & $\frac{\underline{\text { s.id} / q E V o}}{\underline{\mathrm{v}}}$ \\
\hline 5 & $\begin{array}{l}\text { Tengku Ferdyansah } \\
\text { Sofyan (Ulama } \\
\text { Aceh Darussalam) }\end{array}$ & $\begin{array}{l}\text { "Hari-hari ini kita menyaksikan baik dalam bentuk makam } \\
\text { prajurit yang sampai sekarang terlihat nyata. Ratusan mereka } \\
\text { syahid. Menjadi takdir Allah Aceh bagian dari khilafah," }\end{array}$ & $\begin{array}{l}\text { bit.ly/2Fa } \\
\text { op4D }\end{array}$ \\
\hline 6 & $\begin{array}{l}\text { Ulama Aswaja } \\
\text { Rumpun Melayu }\end{array}$ & $\begin{array}{l}\text { "Sudah saatnya Islam menggantikan ideologi gagal yaitu } \\
\text { Kapitalisme dan Komunisme." }\end{array}$ & $\begin{array}{l}\text { s.id/qEX } \\
\mathrm{mq}\end{array}$ \\
\hline 7 & $\begin{array}{l}\text { Ade Sudiana, Lc. } \\
\text { Ulama Jawa Barat }\end{array}$ & “Kalimat Tauhid itu adalah puncak kesucian Islam" & $\begin{array}{l}\text { youtube.c } \\
\text { om/alead } \\
\text { akwah }\end{array}$ \\
\hline 8 & $\begin{array}{l}\text { M. Taufik NT } \\
\text { Ulama Kalimantan }\end{array}$ & "Allah swt mewajibkan berbuat baik (ihsân) pada segala hal" & $\begin{array}{l}\text { youtube.c } \\
\text { om/watc } \\
\text { h?v=yOS3 } \\
\text { O6ypAvw }\end{array}$ \\
\hline
\end{tabular}

Sepuluh agenda dakwah para ulama, habaib dan kyai terbaru di tengah wabah Corona yang pemberitaannya dipublikasikan pada website Shautululama.

\begin{tabular}{|c|c|c|}
\hline No & Jenis Acara & Keterangan \\
\hline 1 & $\begin{array}{l}\text { Multaqa } \\
\text { Ulama }\end{array}$ & $\begin{array}{l}\checkmark \text { Juli 2020, Forum online Multaqa Ulama Ahlus Sunnah wal Jamaah } \\
\text { Depok-Bogor, }\end{array}$ \\
\hline 2 & $\begin{array}{l}\text { Multaqa } \\
\text { Ulama }\end{array}$ & $\begin{array}{l}28 \text { Juni 2020. Multaqa Ulama Aswaja Jatim, yang diselenggarakan } \\
\text { secara online melalui channel Youtube, Multaqa Ulama Aswaja TV, } \\
\text { Suargo Channel, Bromo Bermartabat, dan Kaffah Channel, }\end{array}$ \\
\hline 3 & $\begin{array}{l}\text { Multaqa } \\
\text { Ulama }\end{array}$ & $\begin{array}{l}28 \text { Juni 2020. Multaqa Ulama Aswaja DKI Raya \& Tangsel dilaksanakan } \\
\text { secara online di channel youtube dan facebook Jakarta Qolbu Dakwah }\end{array}$ \\
\hline 4 & $\begin{array}{l}\text { Multaqa } \\
\text { Ulama }\end{array}$ & $\begin{array}{l}27 \text { Juni 2020. Multaqa Ulama Aswaja Tapal Kuda - Bali yang digelar } \\
\text { secara live di channel YouTube Suargo. }\end{array}$ \\
\hline 5 & $\begin{array}{l}\text { Multaqa } \\
\text { Ulama }\end{array}$ & $\begin{array}{l}27 \text { Juni } 2020 \text { diselenggarakan Multaqa Ulama Aswaja Jawa Tengah dan } \\
\text { Daerah Istimewa Yogyakarta (DIY) melalui media zoom dan Channel } \\
\text { Youtube Dakwah Jateng }\end{array}$ \\
\hline 6 & $\begin{array}{l}\text { Multaqa } \\
\text { Ulama }\end{array}$ & $\begin{array}{l}\checkmark 26 \text { Juni 2020. Multaqa Ulama Aswaja Pantura Jatim, yang disiarkan } \\
\text { melalui Channel Youtube Dakwah Giri, }\end{array}$ \\
\hline
\end{tabular}


Kusumah

\begin{tabular}{|c|c|c|c|}
\hline 7 & $\begin{array}{l}\text { Multaqa } \\
\text { Ulama }\end{array}$ & $\checkmark$ & $\begin{array}{l}26 \text { Juni 2020. Multaqo Ulama Aswaja dari Jombang, Kediri, Mojokerto } \\
\text { dan Nganjuk. }\end{array}$ \\
\hline 8 & $\begin{array}{l}\text { Multaqa } \\
\text { Ulama }\end{array}$ & $\checkmark$ & $\begin{array}{l}24 \text { Juni 2020. Multaqa Ulama Aswaja Pantura Jatim, yang disiarkan } \\
\text { melalui Channel Youtube Dakwah Giri, }\end{array}$ \\
\hline 9 & Liqa Ulama & $\checkmark$ & $\begin{array}{l}21 \text { Juni 2020. Liqa Syawal Ulama Aswaja Kalimantan disiarkan secara } \\
\text { live melalui Channel YouTube Ulama Gurunda Tv. }\end{array}$ \\
\hline 10 & $\begin{array}{l}\text { Multaqo dan } \\
\text { Halal bi halal }\end{array}$ & $\checkmark$ & $\begin{array}{l}21 \text { Juni 2020, Multaqa Ulama sekaligus sebagai Halal bi Halal Syawal } \\
1441 \text { H bagi Ulama Tangerang }\end{array}$ \\
\hline
\end{tabular}

Maka kini terbukti bahwa konvergensi media komunikasi tidak hanya dilakukan di lingkungan kampus dan universitas, namun juga dilakukan oleh para ulama, habaib dan kyai. Giatnya dakwah para ulama, habaib dan kyai ini perlu dukungan dari seluruh elemen umat, termasuk generasi muda.

Berbagai majelis Ilmu, mudzakarah ulama, multaqo ulama, liqo ulama, mutamar ulama baik tingkat lokal maupun nasional yang diselenggarakan ratusan para ulama, habaib dan kyai dan dihadiri ribuan peserta kini dapat diikuti pula oleh berbagai segmen usia diantaranya santri muda, mahasantri, remaja masjid, pemuda masjid, mahasiswa Islam, generasi Hijrah, alumni-alumni program tutorial, santri siap guna, yaitu mereka yang masih memiliki gelora dakwah yang membara, termasuk para kakek dan orang-orang tua yang kini banyak beraktifitas di rumah karena telah lanjut usia turut menghadiri acara-acara dakwah melalui kanal Youtube yang ada pada telepon genggam mereka.

Salah satu kanal dakwah di Youtube yang memiliki moto "Insprasi Muslimah Masa Kini" yaitu Muslimah Media Center di antara salah satu contoh kanal Dakwah banyak diikuti oleh berbagai segmen usia khususnya muslimah dengan pengikut mencapai 12.788. (Rahma \& Kusumah, 2020).

Pada Dai Muda ini baik santri ataupun mahasiswa Islam adalah generasi baru umat Islam saat ini, mereka banyak mengakses internet dan menguasai teknologi, maka keterlibatan para Dai Muda adalah penting bagi keberlangsungan dakwah, dan Alhamdulillah mereka pun ikut serta menyimak agenda para ulama ini dan turut pula memberikan support berupa Like, Comment, Subscribe dan Share ke berbagai media sosial. Kini kita menyadari bahwa konvergensi Media Dakwah saat ini bukanlah hal yang asing lagi di telinga kita.

\section{Kesimpulan}

Dari berbagai pemaparan dan penjelasan di atas peneliti mendapatkan simpulan bahwa konvergensi media dakwah adalah adanya kolaborasi berbagai elemen (platform) media yang menjadi sarana dakwah Islam untuk meningkatkan kesadaran umat. Konvergensi media dakwah merupakan integrasi teks, audio, video sebagai sarana dakwah Islam untuk meningkatkan kesadaran umat. Agar pesan semakin dapat sampai kepada sasaran dakwah yang dituju, maka konvergensi pada media dakwah adalah penting digunakan. Wabah Covid-19 saat ini bagi para ulama, habaib dan kyai bukanlah penghalang dakwah dan syiar Islam. 
Konvergensi Media Dakwah telah menjadi inovasi baru dalam geliat dakwah Islam, dan dakwah takkan pernah padam untuk Islam kemuliaan sehingga keberkahan negeri ini dapat diraih.

\section{DAFTAR PUSTAKA}

Google Trends. https://trends.google.com/trends/?geo=ID

Irawan, M. Bagus. (2020). KH Abdullah bin Nuh, Ulama Pejuang dari Bogor yang Terlupakan https://iqra.id/kh-abdullah-bin-nuh-ulama-pejuang-daribogor-yang-terlupakan-222763/

Pratama, S. (2017). Kontribusi Buya HAMKA dalam perkembangan dakwah Muhammadiyah tahun 1925-1981 (Doctoral dissertation, Universitas Islam Negeri Sumatera Utara). http://repository.uinsu.ac.id/3334/1/FDF.pdf

Pujiono, P. (2018). Peran Lembaga Penyiaran Publik (LPP) TVRI Jawa Tengah Dalam Dakwah Islam (Studi Kasus Program Acara Jalan-Jalan Islami TVRI Jawa Tengah Episode Masjid Gede Sendang Harjo Kadilangu Demak) (Skripsi, IAIN SALATIGA). repository.perpus.iainsalatiga.ac.id/4396/1/Semua\%20file\%20CD.pdf

Rizkiyansyah, Beggy. (2014). Lahirnya Pers Islam di Indonesia. https://jejakislam.net/lahirnya-pers-islam-di-indonesia/ Stephens, Mitchell. (-). History of Television.

Rahma, Farida Nur, \& Kusumah, Mada Wijaya. (2020). Youtube Sebagai Media Dakwah Masa Pandemi Covid 19 (Studi Analisis Konten Dakwah Channel Muslimah Media Center 15-30 Juni 2020). Zenodo. http://doi.org/10.5281/zenodo.4018170

Youtube sebagai Media Dakwah Masa Pandemi Covid 19 (Studi Analisis Konten Dakwah Channel Muslimah Media Center 15-30 Juni 2020)

Saleh, E. H. KH. Muhammad Syafi'i Hadzami, riwayat hidup dan perjuangannya di kalangan masyarakat Betawi. http://repository.uinjkt.ac.id/dspace/bitstream/123456789/12516/1/S URYANIH-FAH.pdf

Sasongko, Agung. (2011). Radio Cendrawasih, Syiar Islam Melalui Teknologi Berawal. https://republika.co.id/berita/video/ficer/11/05/16/lla4pcradio-cendrawasih-syiar-islam-melalui-teknologi-berawal

Shautululama, https://shautululama.co/

Sutopo; Misno. Kontribusi Abdullah bin Nuh dalam Pengembangan Pendidikan Islam di Cianjur, Sukabumi dan Bogor, Jawa Barat. AL-MURABBI: Jurnal Studi Kependidikan dan Keislaman. 2017;4(1):71-84 http://ejournal.kopertais4.or.id/mataraman/index.php/murabbi/article/ view/3084/2281

Telegram Analytics, https://tgstat.com/

Wahid, Din, \& Makruf, Jamhari. (2017). Suara Salafisme Radio Dakwah di Indonesia. Kencana.

Wardhani, H. C. K. (2014). Strategi Pemrograman Lembaga Penyiaran Publik TVRI. Jurnal Unair. http://journal.unair.ac.id/filerPDF/comme56d95f0c0full.pdf 